\title{
An enhanced software tool to support better use of manure nutrients: MANNER-NPK
}

F. A. Nicholson ${ }^{1}$, A. Bhogal ${ }^{1}$, D. Chadwick ${ }^{2}$, E. Gill ${ }^{3}$, R. D. Gooday ${ }^{3}$, E. Lord $^{3}$, T. Misselbrook $^{4}$, A. J. Rollett ${ }^{1}$, E. $\mathrm{Sagoo}^{5}, \mathrm{~K} \cdot \mathrm{A} \cdot \mathrm{Smith}^{3}$, R. E. Thorman ${ }^{5}, \mathrm{~J}$. R. Williams ${ }^{5}$ \& B. J. Chambers ${ }^{1}$

${ }^{1}$ ADAS Gleadthorpe, Meden Vale, Mansfield, Nottinghamshire, NG20 9PD, UK, ${ }^{2}$ School of Environment, Natural Resources and Geography, Bangor University, Deiniol Road, Bangor, LA57 2UW, UK, ${ }^{3} A D A S$ Wolverhampton, Pendeford House, Pendeford

Business Park, Wobaston Road, Wolverhampton, WV9 5AP, UK, ${ }^{4}$ Rothamsted Research, North Wyke, Okehampton, Devon, EX20 2SB, UK, and ${ }^{5} A D A S$ Boxworth, Boxworth, Cambridge, CB23 $4 N N$, UK

\begin{abstract}
MANNER-NPK (MANure Nutrient Evaluation Routine) is a decision support tool for quantifying manure (and other organic material) crop available nutrient supply. The user-friendly design of an earlier version of MANNER was retained, but in response to user and stakeholder feedback, additional functionality was included to underpin new and revised nitrogen $(\mathrm{N})$ transformation/loss modules (covering ammonia volatilization, nitrate leaching and nitrous oxide/di-nitrogen emissions, and organic $\mathrm{N}$ mineralization) and also to estimate manure phosphorus (as $\mathrm{P}_{2} \mathrm{O}_{5}$ ), potassium (as $\mathrm{K}_{2} \mathrm{O}$ ), sulphur (as $\mathrm{SO}_{3}$ ) and magnesium (as $\mathrm{MgO}$ ) supply. Notably, MANNER-NPK provides $\mathrm{N}$ availability estimates for following crops through the mineralization of organic N. Validation of the crop available $\mathrm{N}$ supply estimates was undertaken by comparing predicted values with data from more than 200 field experimental measurements. For cattle, pig and poultry manures, there was good agreement $(P<0.001)$ between predicted and measured fertilizer $\mathrm{N}$ replacement values, indicating that MANNER-NPK provides robust estimates of manure crop available $\mathrm{N}$ supply and $\mathrm{N}$ losses to the wider environment.
\end{abstract}

Keywords: Manures, nutrients, nitrogen, crop availability, losses, decision support tool

\section{Introduction}

Land application is the most cost-effective outlet for recycling farm manures and other organic materials (e.g. biosolids, composts, digestates), enabling plant available nutrients and organic matter to be utilized to contribute to crop nutrient demands and maintain soil fertility. However, in many countries, farmers do not always make adequate allowance for the contribution of organic materials to crop nutrient requirements, potentially resulting in nutrient oversupply and subsequent environmental pollution. Increasing the contribution of organic materials to crop nutrient requirements is essential in reducing nitrate $\left(\mathrm{NO}_{3}\right)$ and phosphorus (P) losses to water systems, and ammonia $\left(\mathrm{NH}_{3}\right)$ and nitrous oxide $\left(\mathrm{N}_{2} \mathrm{O}\right)$ emissions to air from

Correspondence: F. A. Nicholson. E-mail: fiona.nicholson@ adas.co.uk

Received March 2013; accepted after revision July 2013 agriculture, to comply with existing and forthcoming EU Directives and International agreements (e.g. Nitrates Directive, Water Framework Directive, National Emission Ceilings Directive, Kyoto Protocol etc.).

The ADAS MANure Nitrogen Evaluation Routine (MANNER version 3.0) decision support system was originally developed to predict crop available $\mathrm{N}$ supply following farm manure (and other organic material) applications to land, taking into account manure $\mathrm{N}$ analysis, $\mathrm{NH}_{3}$ volatilization and $\mathrm{NO}_{3}$ leaching losses, and the mineralization of organic $\mathrm{N}$ (Chambers et al., 1999). Over 10000 copies have been distributed following its launch in August 2000. A new version of the software (MANNER$N P K$; Figure 1) was developed to enhance the $\mathrm{N}$ loss and crop available $\mathrm{N}$ supply predictions by utilizing more recent scientific information. In response to user and stakeholder feedback, the software functionality was also extended to include predictions of phosphorus (as $\mathrm{P}_{2} \mathrm{O}_{5}$ ), potassium (as $\mathrm{K}_{2} \mathrm{O}$ ), sulphur (as $\mathrm{SO}_{3}$ ) and magnesium (as $\mathrm{MgO}$ ) supply to 
(i)

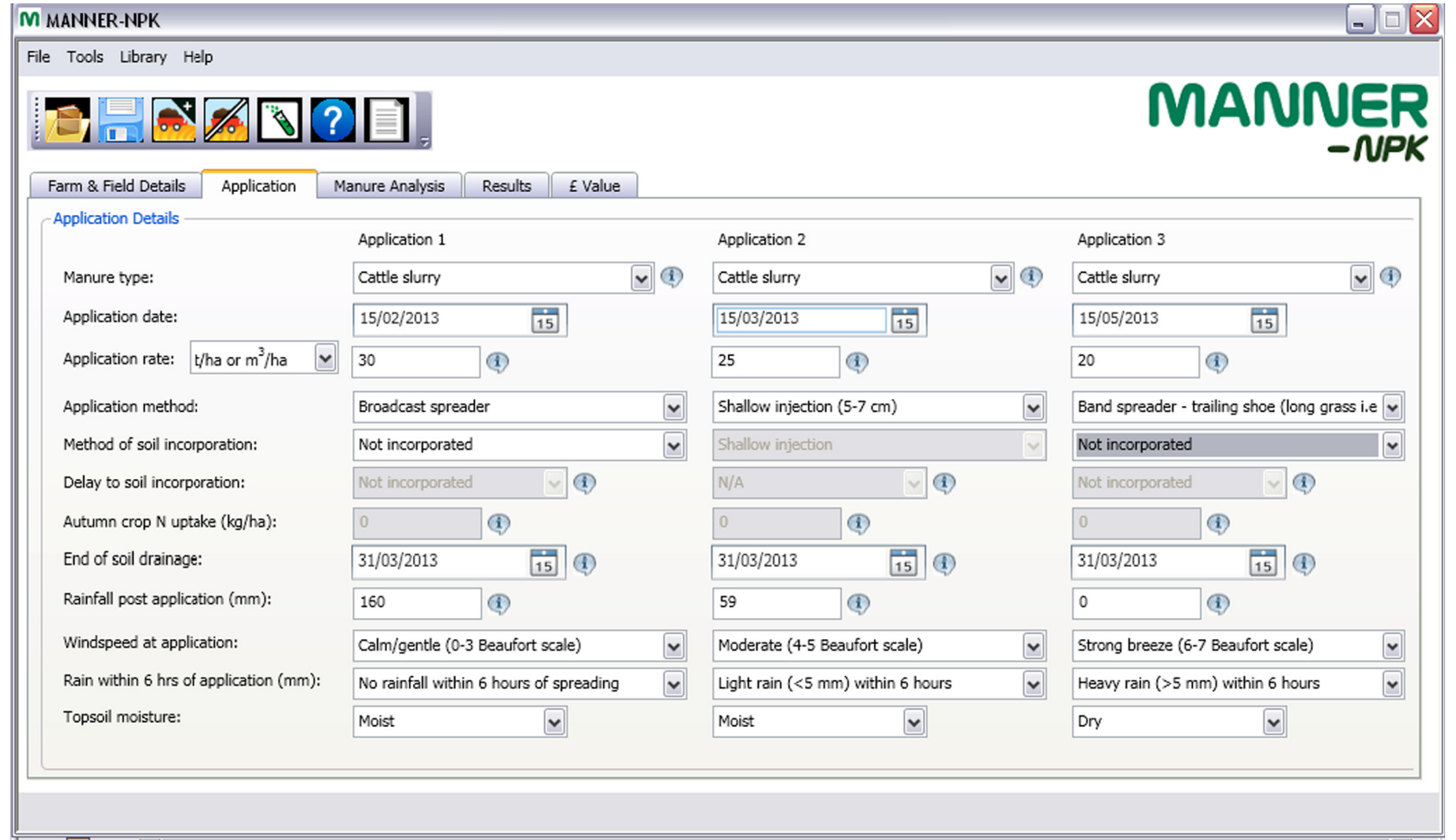

(ii)

\section{MANNER-NPK}

File Tools Library Help

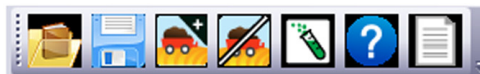

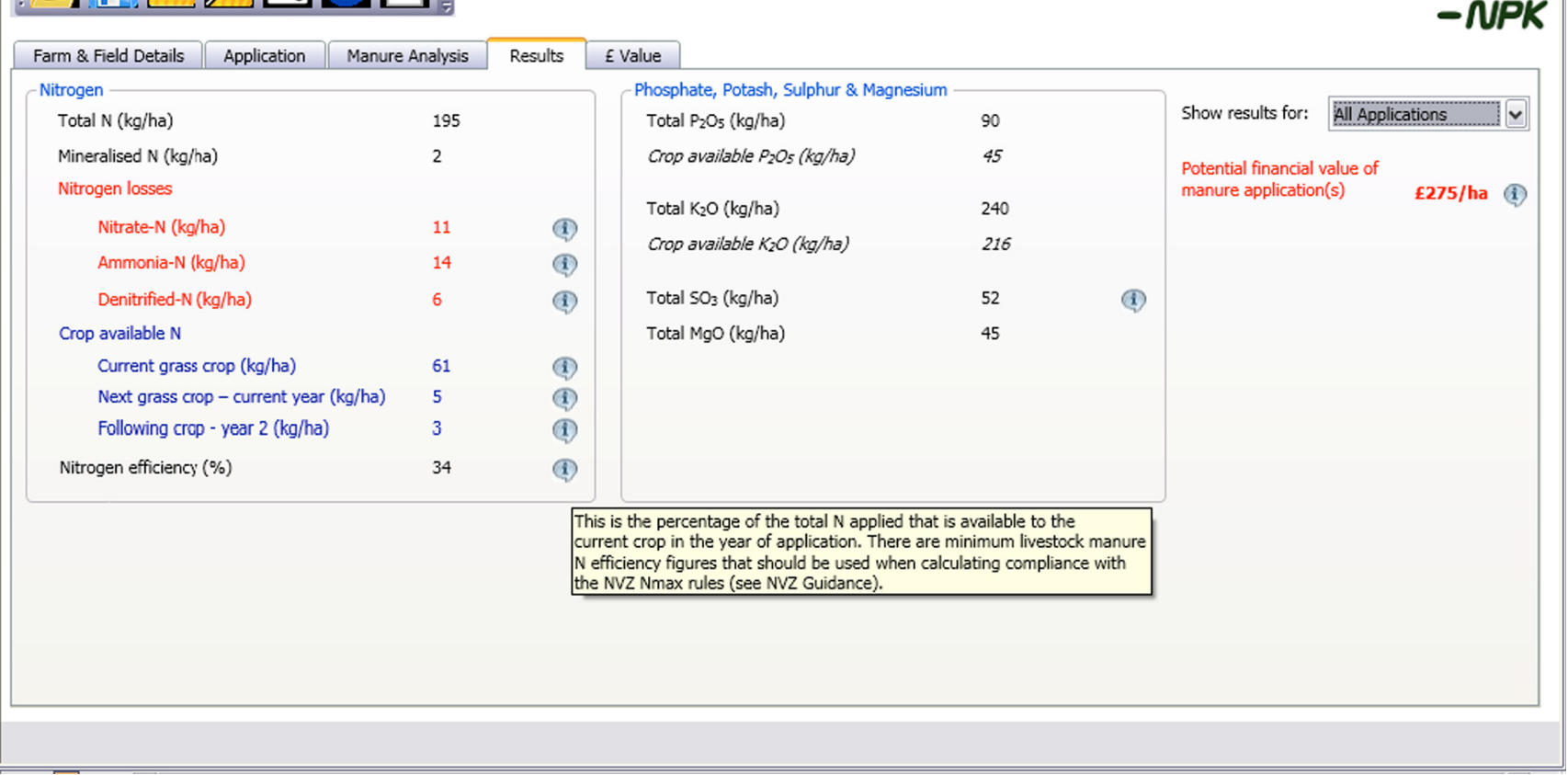

Figure 1 MANNER-NPK screenshot examples (i) Application tab, showing details for three cattle slurry applications to grassland in spring and (ii) Results tab, showing MANNER-NPK estimates of N losses and fertilizer nutrient replacement values of the three cattle slurry applications. 
crops, and to enable users to view the results in terms of both the fertilizer replacement value $(\mathrm{kg} / \mathrm{ha})$ and the economic value $(\mathfrak{f} / \mathrm{ha})$ of manure applications.

\section{Methods}

The MANNER conceptual model was enhanced to incorporate new modules to estimate $\mathrm{N}_{2} \mathrm{O}$ (via nitrification and denitrification) and di-nitrogen $\left(\mathrm{N}_{2}\right)$ losses (via denitrification), and to take into account autumn crop $\mathrm{N}$ uptake (Figure 2). Some changes were also made to the inter-relationships between modules to better represent the $\mathrm{N}$ flow pathways and transformations that occur following manure application to land. In particular, MANNER-NPK now estimates the quantity of $\mathrm{N}$ available to following crops (i.e. in the cropping year after manure application) through the release of manure organic $\mathrm{N}$.

The MANNER modules were updated as described in the following sections.

\section{Manure nutrient analysis}

The manure nutrient analysis database was revised on the basis of more recent analytical data. Manure P, K, S and $\mathrm{Mg}$ analyses can now also be entered to provide a prediction of the total and crop available supply of these nutrients. In addition, 'default' nutrient contents for 'new' manure types (e.g. green compost, digestates) have been included, together with nitrate- $\mathrm{N}$ analysis data, which can be an important source of readily available $\mathrm{N}$ from some manures.

MANNER-NPK adjusts the 'default' total and readily available $\mathrm{N}$ contents of slurry based on dry-matter content. Similarly, equations are embedded in the software relating slurry and poultry manure dry matter to $\mathrm{P}, \mathrm{K}, \mathrm{S}$ and $\mathrm{Mg}$ contents (Defra, 2010).

\section{Ammonia volatilization}

Standard ammonia volatilization curves. Ammonia volatilization is the first major loss pathway for manure $\mathrm{N}$ following land application. The 'standard' ammonia volatilization curves for different manures were updated using data from micrometeorological measurements of ammonia emissions from broadcast manures at a range of sites in England, under grassland and arable cropping. MichaelisMenten type equations (Sommer \& Ersboll, 1994) were fitted to each experimental dataset (equation 1) using GenStat:

$$
\text { Ammonia lost at time }(\mathrm{t})=\mathrm{N}_{\max } *\left(\mathrm{t} /\left(\mathrm{t}+\mathrm{K}_{\mathrm{m}}\right)\right)
$$

where $\mathrm{N}_{\max }$ is the maximum $\mathrm{N}$ loss as time (t) approaches infinity (expressed as a percentage of the manure readily available $\mathrm{N}$ - RAN - applied) and $\mathrm{K}_{\mathrm{m}}$ is the time (in $\mathrm{h}$ ) when half of $\mathrm{N}_{\max }$ has been lost. Note: RAN is the sum of the manure ammonium- $\mathrm{N}$ and, for poultry manures, uric acid-N contents. In total, four 'standard' emission curves were defined (Table 1). Experimental data on ammonia emissions from the other organic material types included in MANNER-NPK (e.g. biosolids, digestates, composts) were not available. Hence, it was assumed that emissions from these materials followed one of the four standard curves and any additional ammonia loss rules for that manure type, as described in Figure 3.

Factors influencing ammonia volatilization. Based on experimental data not previously taken into account (e.g. Smith et al., 2000; Sogaard et al., 2002; Misselbrook et al., 2004), the ammonia loss algorithms were modified to take account of factors which had been shown to influence ammonia volatilization from field-applied manures (i.e. soil moisture content, land use, wind speed, rainfall after spreading, slurry dry-matter content, slurry application technique, soil incorporation technique and timing). Ammonia volatilization losses from each of the four broad manure types were adjusted according to decision support rules summarized in Figure 3.

For cattle slurry, an initial adjustment to the $\mathrm{N}_{\max }$ is made based on the soil moisture status, as ammonia emissions from cattle slurry applied to 'dry' soils in summer (i.e. where soil moisture is below field capacity) were found to be greater than from 'moist' soils in the autumn-to-spring period (i.e. where soils are at field capacity), due to a combination of the hydrophobic effect of dry soil conditions on slurry infiltration and also higher temperature/lower humidity conditions in the summer (Smith et al., 2000). A further adjustment to the $\mathrm{N}_{\max }$ is made based on land use, as losses from grassland soils are typically higher than from arable soils (Smith et al., 2000).

For both cattle and pig slurry, relationships between slurry dry-matter (DM) content and ammonia emissions have been observed where applications were made to grassland under 'moist' soil conditions (e.g. Sogaard et al., 2002; Misselbrook et al., 2004). Ammonia emission and DM relationships were included for slurries applied to moist soils in the autumn-to-spring period, based on data from Misselbrook et al. (2004). These relationships were used to derive an adjustment to $\mathrm{N}_{\max }$ compared with emissions from cattle slurry at $6 \% \mathrm{DM}$ and pig slurry at $4 \%$ DM.

An adjustment to the $\mathrm{N}_{\max }$ for slurries is also made based on evidence that precision slurry application techniques (i.e. bandspreaders and shallow injectors) reduce ammonia emissions following land spreading (e.g. Smith et al., 2000; Misselbrook et al., 2002). As wind speed and rainfall at or around the time of slurry spreading also influence ammonia losses (Misselbrook et al., 2004), further adjustments to $\mathrm{N}_{\max }$ are made based on these factors (Figure 3). 


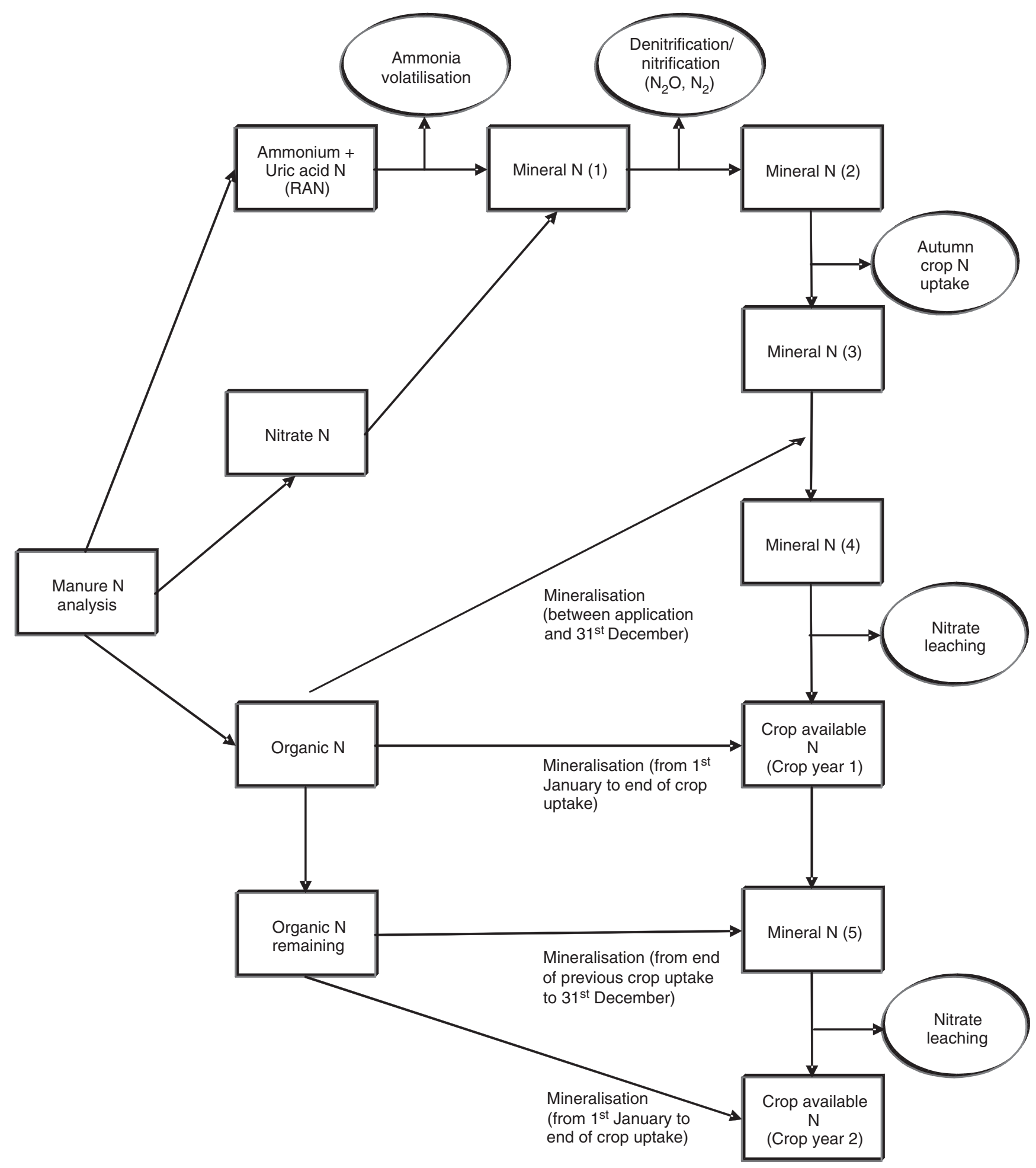

Figure 2 The MANNER-NPK conceptual model.

Soil incorporation technique affects ammonia emission mitigation efficiency and the subsequent emission rate, with the reduction in emission also dependent on manure type. Ammonia loss up to the time of soil incorporation (t) is calculated using the Michaelis-Menten equation (equation 1) with the $\mathrm{K}_{\mathrm{m}}$ specified in Table 1 , and an adjusted $\mathrm{N}_{\max }$ value based on the manure type and soil incorporation technique (Table 2). Soil incorporation timings take into 
Table 1 Michaelis-Menten equation parameters for the 4 'standard' ammonia loss curves

\begin{tabular}{lccr}
\hline $\begin{array}{l}\text { Standard } \\
\text { curve }\end{array}$ & Measurements & $\begin{array}{c}\mathrm{N}_{\max } \\
\text { (\%RAN applied) }\end{array}$ & $\begin{array}{c}\mathrm{K}_{\mathrm{m}} \\
(\mathrm{h})\end{array}$ \\
\hline Cattle slurry $^{\mathrm{a}}$ & 42 & 32.4 & 7.5 \\
Pig slurry $^{\mathrm{b}}$ & 5 & 25.5 & 11.6 \\
$\begin{array}{l}\text { FYM (cattle, } \\
\text { pig and duck) }\end{array}$ & 8 & 68.3 & 14.9 \\
Poultry manure $^{\mathrm{d}}$ & 11 & 52.3 & 40.4 \\
\hline
\end{tabular}

${ }^{a}$ curve also used for dirty water, cattle slurry-based digestate and liquid-digested sludge, ${ }^{\mathrm{b}}$ curve also used for food and pig slurry-based digestate, and all categories of food 'waste', 'curve also used for green and green/food compost, and paper crumble, ${ }^{\mathrm{d}}$ curve also used for digested sludge cake, thermally dried sludge, lime-stabilized sludge and composted sludge.

account the different shape of the standard emission curves (i.e. losses from poultry manure occur more slowly than from slurry and FYM). Ammonia emissions are assumed to continue after soil incorporation, albeit at a lower rate.

\section{Nitrate leaching losses}

The MANNER-NPK leaching module was enhanced to improve nitrate leaching loss predictions from freely drained sandy or silty soils where leaching occurs largely via matrix flow, and from poorly drained clay soils where leaching mainly occurs via bypass (crack) flow. These enhancements were based on data from field experiments quantifying nitrate leaching losses following a range of livestock manure applications to freely drained soils (e.g. Beckwith et al., 1998; Chambers et al., 2000) and poorly drained soils (e.g. Williams et al., 2006).

Freely drained soils. Nitrate leaching algorithms were derived from the models of Burns (1974) and Addiscott (1977), which describe losses via matrix flow, with nitrate moving down with infiltrating water as it displaces soil water. The leaching curve for freely drained soils is bell-shaped, but 'stretches out' at higher hydrologically effective rainfall HER values (Figure 4), where HER is defined as rainfall minus evapotranspiration. Approximately half of the nitrate placed at the soil surface will have leached beyond $90 \mathrm{~cm}$ depth when the volume of water (i.e. HER), which has passed through the overlying soil is equal to the water content of that soil (i.e. the volumetric moisture content $\mathrm{Vm})$ at field capacity (0.05 bar). Thus, leaching begins after about half of the soil $\mathrm{Vm}$ has been displaced and is largely complete after twice the $\mathrm{Vm}$ has been displaced. Due to differences in the soil $\mathrm{Vm}$ content, nitrate is lost more rapidly from sandy soils and (some) shallow soils over rock, compared with silty soils.
When manures are ploughed down or incorporated by discs or tines, the topsoil component of the $\mathrm{Vm}$ is reduced, to account for the reduced depth of soil through which the nitrate has to move. If there was a soil moisture deficit during the leaching calculation period, the HER is reduced by a factor of 0.7 of this deficit.

Poorly drained soils. In poorly drained (clay) soils, the infiltration capacity of the soil matrix is limited and much of the HER which subsequently reaches surface water systems will pass through the soil via cracks, mole channels and drains (i.e. via bypass flow), allowing incomplete equilibration with the soil matrix. MANNER-NPK simulates these losses using a simplified version of the EDEN model (Gooday et al., 2008) using the HER and the volumetric moisture content as per the model for freely drained soils. The total nitrate lost from a poorly drained soil is predicted to be smaller than that lost from a freely drained soil, because a large part of the HER bypasses the soil matrix.

Nitrification. The rate at which manure ammonium-N is nitrified to nitrate- $\mathrm{N}$ is largely temperature driven and will affect the amount and timing of over-winter nitrate leaching losses. As a result, a 'nitrification delay' function has been incorporated into MANNER-NPK to account for delays in nitrate production (and therefore leaching). Using data from Bradbury et al. (1993), nitrification rates of manure ammonium-N were calculated on a monthly basis. The time taken for $50 \%$ of the ammonium-N to be nitrified was determined as this was assumed to be when leaching began (i.e. the majority of the ammonium- $\mathrm{N}$ had been nitrified into the 'mobile' nitrate form). For simplicity, MANNER-NPK 'adds' the time taken for $50 \%$ of the manure ammonium-N to be nitrified (depending on the month of application) to the manure application date.

Crop available $\mathrm{N}$ supply may also be influenced by immobilization of manure ammonium-N; for example, in laboratory experiments, Burger \& Venterea (2008) found that $14-40 \%$ of applied manure ammonium-N was immobilized. However, there was not enough evidence from UK field experiments for immobilization processes to be included in this version of MANNER-NPK.

Hydrologically effective rainfall. Calculation of nitrate leaching requires an estimate of the amount of HER. A simple soil drainage model (as used in the PSYCHIC model; Davison et al., 2008) calculates monthly values for rainfall, evapotranspiration and HER, and an end of drainage date for representative tillage land and permanent grassland situations under mean climate conditions at the selected site. 


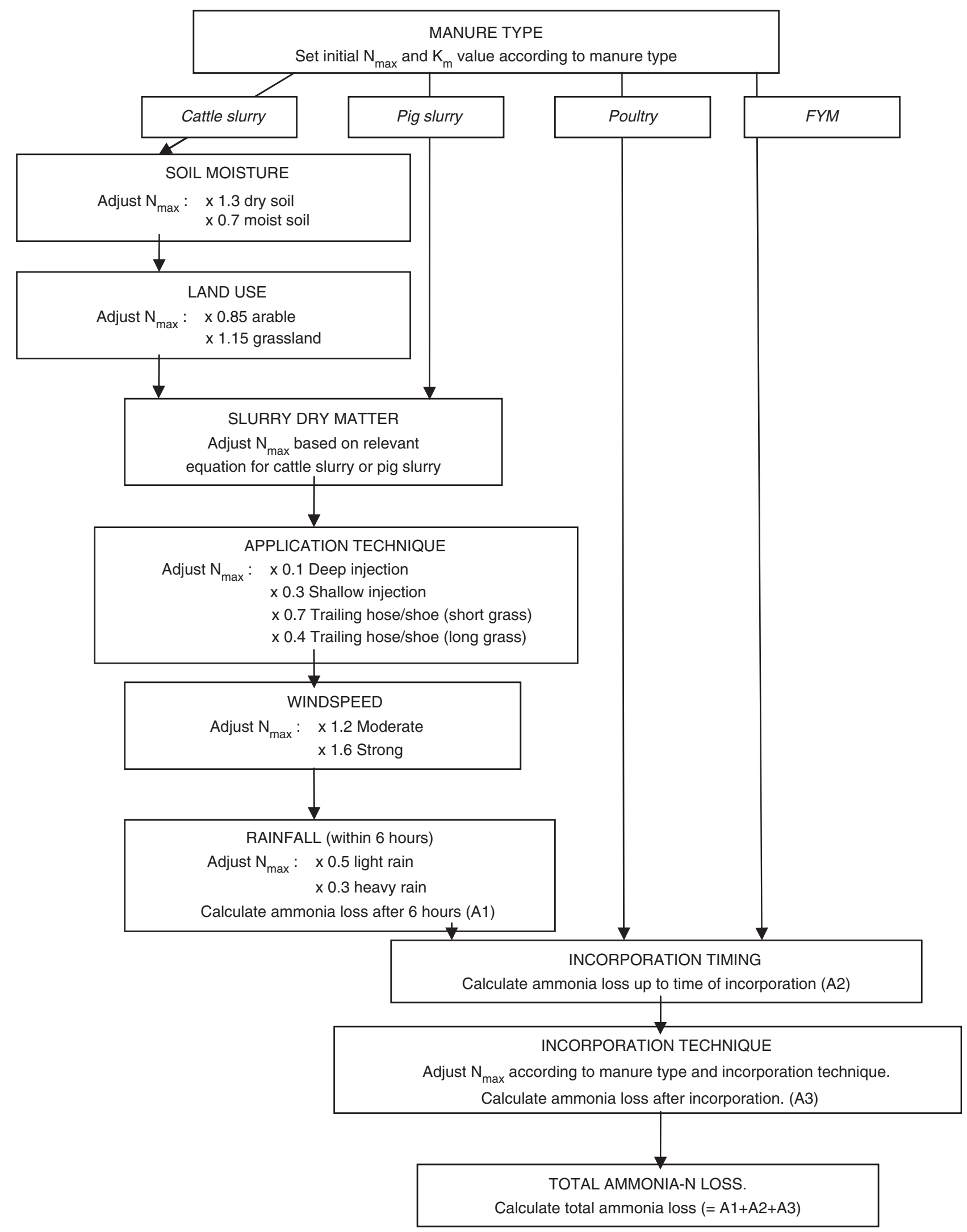

Figure 3 Decision support rules for the MANNER-NPK ammonia module. 
Table 2 Soil incorporation technique and adjustment factor applied to $\mathrm{N}_{\max }$

\begin{tabular}{lccc}
\hline & \multicolumn{3}{c}{ Adjustment to $\mathrm{N}_{\max }$} \\
\cline { 2 - 4 } $\begin{array}{l}\text { Incorporation } \\
\text { technique }\end{array}$ & FYM & Poultry & Slurry \\
\hline Plough & 0.1 & 0.05 & 0.1 \\
Rotavator & 0.2 & 0.1 & 0.15 \\
Disc & 0.3 & 0.2 & 0.2 \\
Tine & 0.7 & 0.3 & 0.3 \\
\hline
\end{tabular}

The climate data were taken from a $5 \times 5 \mathrm{~km}$ spatial resolution map for 1971-2000 (sourced from the Climate Research Unit, University of East Anglia) and interpolated to provide unique values for UK postcodes.

\section{Manure organic $N$ mineralization}

Manure organic $\mathrm{N}$ mineralization is a microbially mediated process, with temperature an important driving factor (Swift et al., 1979). A number of workers have used temperature to predict organic $\mathrm{N}$ mineralization, where temperature was represented as thermal time, that is, cumulative day degrees (CDD) above $5{ }^{\circ} \mathrm{C}$ for soil temperatures at $10 \mathrm{~cm}$ depth (e.g. Douglas \& Rickman, 1992; Clough et al., 1998).

In MANNER-NPK, field experimental data were used to derive relationships between net manure organic $\mathrm{N}$ mineralization and thermal time after application (Williams et al., 1998, 1999). Organic N mineralization curves, which have been shown to improve the accuracy of predicting manure organic $\mathrm{N}$ availability (e.g. Klausner et al., 1994), were produced for different manure types. Net organic $\mathrm{N}$ mineralization rates were found to be much greater up to 2300 CDD than after 2300 CDD; rates were linearly related to thermal time in both phases, but varied with manure type. The relationships fell into two broad groups, with pig slurry and poultry manure having a higher rate of organic $\mathrm{N}$ mineralization than cattle/pig FYM and cattle slurry.

Experimental data on organic $\mathrm{N}$ mineralization from other organic manure types (e.g. biosolids, digestates, composts) were not available. It was therefore assumed that $\mathrm{N}$ mineralization from these materials followed either the FYM/cattle slurry ('low' mineralization - compost, dirty water, cattle slurry-based digestate) or pig slurry/poultry manure ('high' mineralization - all biosolids types, food/pig slurry-based digestate, food 'waste') relationships.

\section{Emissions of nitrous oxide and di-nitrogen}

MANNER-NPK now includes estimates of $\mathrm{N}$ losses via denitrification and nitrification as $\mathrm{N}_{2} \mathrm{O}$ and $\mathrm{N}_{2}$. Although these losses are generally small in agronomic terms, $\mathrm{N}_{2} \mathrm{O}$ is an important greenhouse gas with a global warming potential ca. 300 times greater than $\mathrm{CO}_{2}$ (IPCC, 2007). The production of $\mathrm{N}_{2} \mathrm{O}$ is predominantly carried out by nitrifying and denitrifying micro-organisms, with many management and soil factors influencing emissions following manure application to land (Granli \& Bøckman, 1994).

Within the UK Greenhouse Gas Emissions Inventory, agricultural $\mathrm{N}_{2} \mathrm{O}$ emissions are currently calculated using the Intergovernmental Panel on Climate Change (IPCC) methodology (IPCC, 1997). In the most recent IPPC methodology, direct manure $\mathrm{N}_{2} \mathrm{O}$ emissions from soil following manure application, estimated using the Tier 1 IPCC default emission factor (EF), are based on total $\mathrm{N}$ applied (IPCC, 2006). However, Clemens \& Ahlgrimm (2001) highlighted the importance of accounting for differing ammonia $\mathrm{N}$ losses following manure application.

The $\mathrm{N}_{2} \mathrm{O}$ EF used in MANNER-NPK was derived from a database of field studies carried out between 1994 and 2003 on a range of grassland and arable sites in England (e.g. Misselbrook et al., 1998; Chadwick et al., 2000b; Thorman et al., 2003, 2006, 2007). Data were only included if the length of the measurement period was $>21$ days. However, the majority of EFs were generated from measurement periods of <90 days; so MANNER-NPK is likely to
Figure 4 Nitrate leaching function for freely drained soils (assuming $100 \mathrm{~kg} / \mathrm{ha}$ nitrate-N from applied manure).

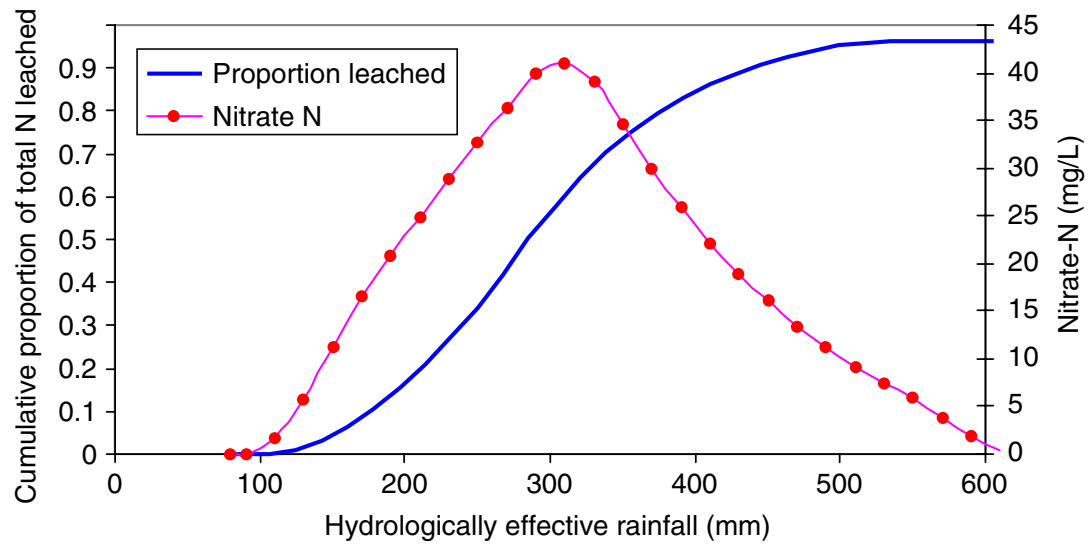



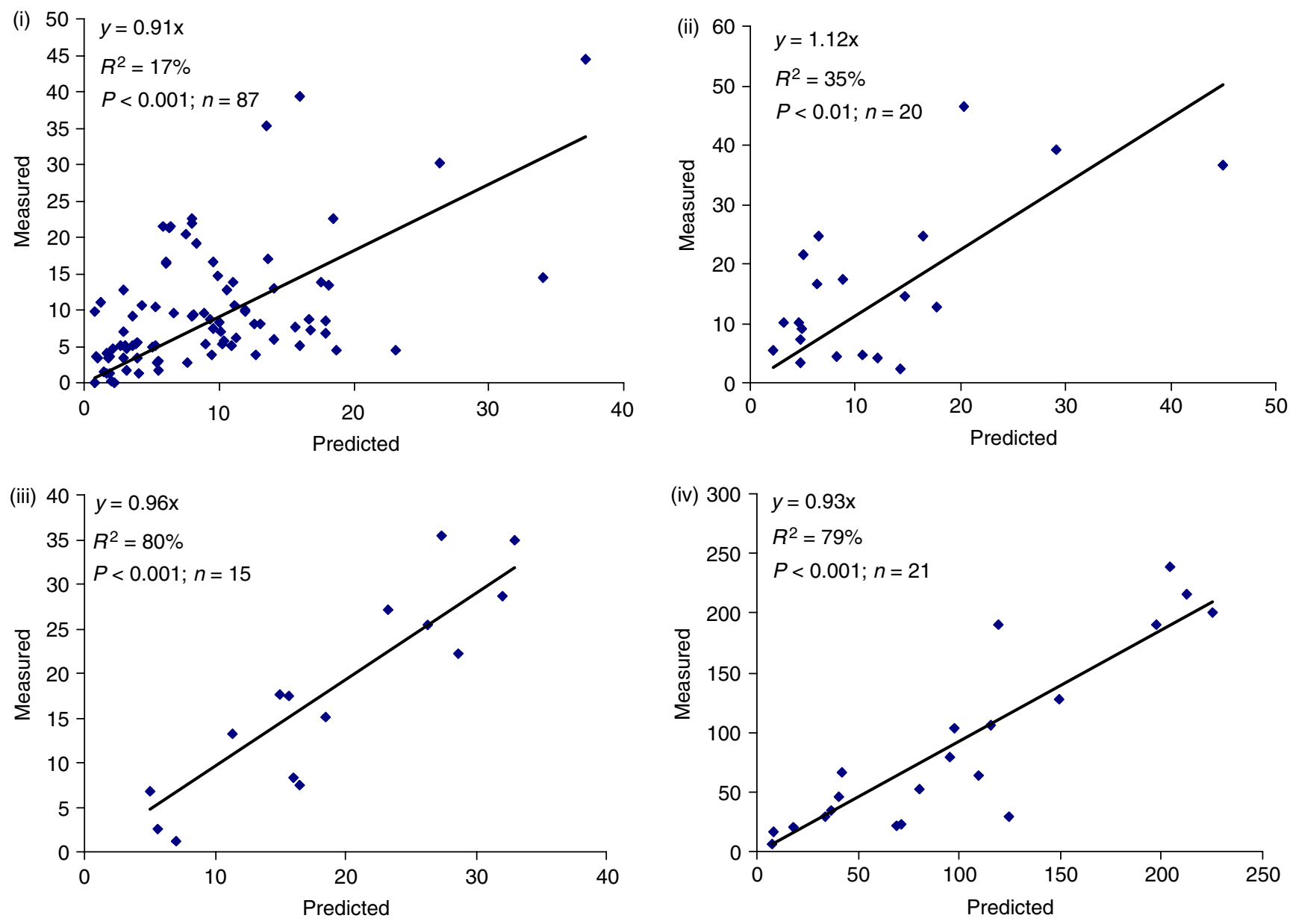

Figure 5 Predicted and measured ammonia emissions ( $\mathrm{kg} \mathrm{N} / \mathrm{ha}$ ) from (i) cattle slurry, (ii) pig slurry, (iii) farmyard manure and (iv) poultry manure.

underestimate $\mathrm{N}_{2} \mathrm{O}$ emissions to some extent compared with whole-year emission measurements.

The EF following manure application was calculated from the amount of RAN remaining after $\mathrm{NH}_{3}$ volatilization, assuming that $\mathrm{N}_{2} \mathrm{O}$ emissions from organic $\mathrm{N}$ mineralization would be relatively small. There were no differences $(P>0.05)$ in EFs between manure types or between land uses, and no consistent effects of slurry application method or soil incorporation practice on $\mathrm{N}_{2} \mathrm{O}$ emissions. Given the relative paucity of data and lack of consistency between studies, a single $\mathrm{N}_{2} \mathrm{O}$ EF of ca. $2 \%$ of applied RAN remaining after ammonia volatilization loss was used. An $\mathrm{N}_{2}: \mathrm{N}_{2} \mathrm{O}-\mathrm{N}$ loss ratio of ca. 3:1 (i.e. 3 times more $\mathrm{N}_{2}-\mathrm{N}$ is lost than $\mathrm{N}_{2} \mathrm{O}-\mathrm{N}$ ) was derived from a database containing results from 21 experimental studies where both $\mathrm{N}_{2} \mathrm{O}$ and $\mathrm{N}_{2}$ were measured following manure application (Ryden et al., 1987). The $\mathrm{N}_{2} \mathrm{O}-\mathrm{N}$ and $\mathrm{N}_{2}-\mathrm{N}$ EFs were applied to the RAN remaining after ammonia volatilization losses (Figure 2). Indirect $\mathrm{N}_{2} \mathrm{O}$ losses (i.e. from nitrate leaching and redeposition of ammonia) were not considered as they do not affect the quantity of $\mathrm{N}$ available to a crop.

\section{Autumn crop $N$ uptake}

Uptake of manure $\mathrm{N}$ by a crop established/growing after a late summer/autumn manure application will affect the amount of $\mathrm{N}$ potentially susceptible to over-winter loss by nitrate leaching. Generally, significant amounts of $\mathrm{N}$ will only be taken up by grassland, oilseed rape and early sown winter cereals, and autumn crop $\mathrm{N}$ uptake will effectively cease by the end of October. MANNER-NPK assumes that if manure was applied in late summer/autumn, then autumn crop $\mathrm{N}$ uptake, based on data published in Defra (2010), is subtracted from the amount of $\mathrm{N}$ potentially at risk from over-winter loss by nitrate leaching (Figure 2).

\section{Crop $N$ available in year 2}

The release of manure organic $\mathrm{N}$ has been shown to continue at a low rate for a number of months/years after application (e.g. Williams et al., 1998, 1999; Chadwick et al., 2000a; Schröder et al., 2007). MANNER-NPK estimates the $\mathrm{N}$ available to following crops by assuming that the $\mathrm{N}$ 

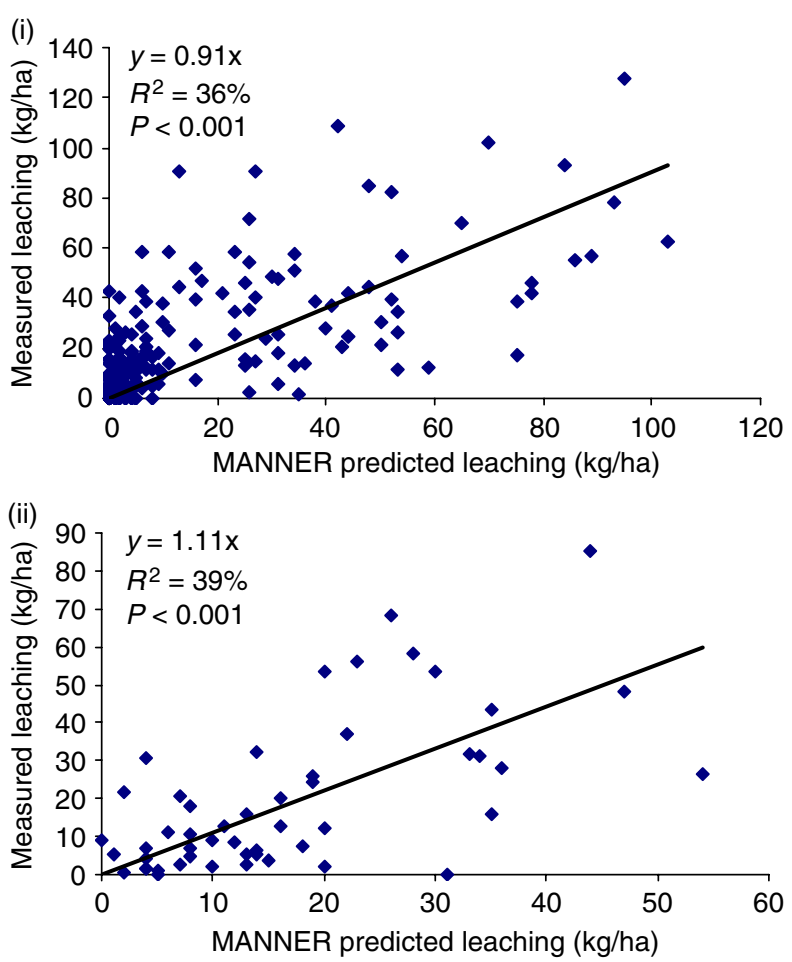

Figure 6 Predicted and measured nitrate leaching losses $(\mathrm{kg} \mathrm{N} / \mathrm{ha}$ from (i) freely drained soils and (ii) poorly drained soils.

released between the end of crop uptake in year 1 and the following 31st December is susceptible to loss by nitrate leaching, but that $\mathrm{N}$ released from 1st January onwards will not be leached. The $\mathrm{N}$ available to the following crop is the sum of these two components (assuming that there are no further losses from $\mathrm{N}_{2} \mathrm{O} / \mathrm{N}_{2}$ emissions).

\section{Model validation}

Validation of the individual $\mathrm{N}$ modules was undertaken wherever suitable field experimental data were available to verify the accuracy of MANNER-NPK predictions. The data used covered a range of manure types, application and soil incorporation techniques/timings, soil types, crops and environmental conditions. Ammonia volatilization estimates were validated against data from $>140$ measurements undertaken between 1994 and 2001, where ammonia emissions had been measured using the micrometeorological mass balance technique (Misselbrook et al., 2005). Estimates of nitrate leaching were validated against $>250$ measurements made between 1990 and 2006 (e.g. Beckwith et al., 1998; Chambers et al., 2000; Williams et al., 2006), where nitrate leaching was measured using porous ceramic cups (freely drained soils) or from hydrologically isolated plots (poorly drained soils). Validation of crop available $\mathrm{N}$ predictions was undertaken using data from more than 200 field experimental studies (e.g. Chambers et al., 1994, 1996;
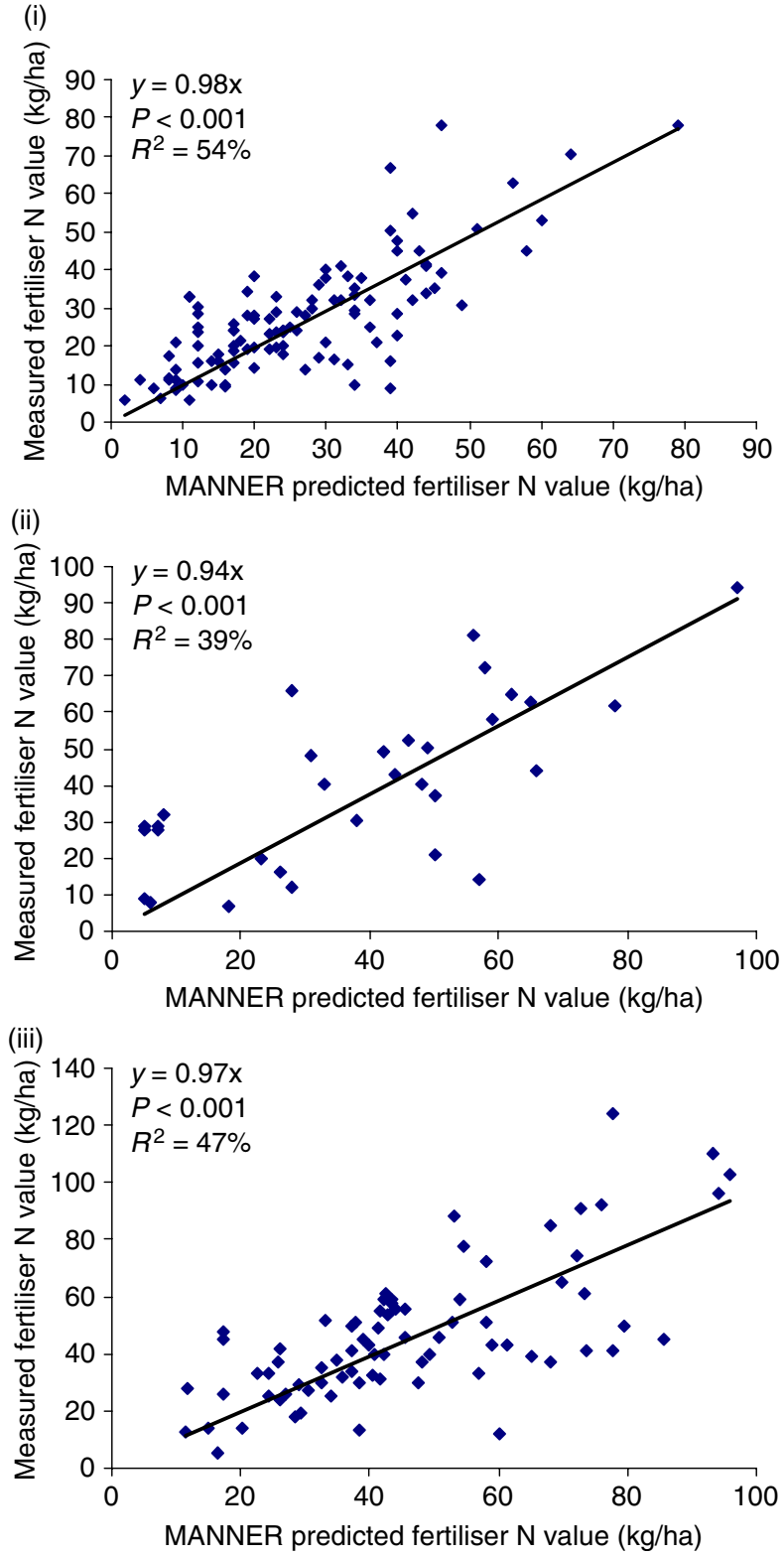

Figure 7 Predicted and measured fertilizer $\mathrm{N}$ replacement values ( $\mathrm{kg} / \mathrm{ha}$ ) for (i) cattle, (ii) pig and (iii) poultry manures.

Jackson \& Smith, 1997) where manure fertilizer N replacement values had been quantified.

\section{Enhancements to the user interface}

Despite considerable modifications and improvements MANNER-NPK has retained the user-friendly design of earlier versions, whilst providing users with enhanced functionality. The requirements for extra data inputs are relatively minor and restricted to information that can be readily obtained (e.g. crop type, wind speed and soil moisture content). 
Importantly, manure $\mathrm{P}, \mathrm{K}, \mathrm{S}$ and $\mathrm{Mg}$ analysis data can now be entered to provide a prediction of the total and crop available $\mathrm{P}$ (as $\mathrm{P}_{2} \mathrm{O}_{5}$ ), $\mathrm{K}$ (as $\mathrm{K}_{2} \mathrm{O}$ ), $\mathrm{S}$ (as $\mathrm{SO}_{3}$ ) and $\mathrm{Mg}$ (as $\mathrm{MgO}$ ) supply, based on figures published in the 'Fertiliser Manual (RB209)' (Defra, 2010), Figure 1.

\section{Results and discussion}

Ammonia emissions. Validation of MANNER-NPK ammonia volatilization predictions from each of the four manure type groups (i.e. cattle slurry, pig slurry, FYM and poultry manure) is shown in Figure 5. For each manure type group, the slope of the regression line was not significantly $(P>0.05)$ different from 1.0, indicating good agreement between predicted and measured ammonia emissions $(P<0.01)$.

Nitrate leaching. For both freely and poorly drained soils, the slope of the regression of MANNER-NPK predicted values against measured values was not significantly $(P>0.05)$ different from 1.0, indicating quantitative agreement between predicted and measured nitrate leaching losses (Figure 6). Furthermore, the relationship between the predicted and measured values was highly significant $(P<0.001)$.

Crop available $N$. Validation showed that for cattle, pig and poultry manures, relationships between predicted and measured fertilizer $\mathrm{N}$ replacement values were highly significant $(P<0.001)$, Figure 7 . Also, the slope of the line was not significantly different from 1.0, indicating that MANNER-NPK predictions were robust $\left(R^{2}=54,39\right.$ and $47 \%$, respectively).

To date, testing has been restricted to UK field situations; however, it should be possible to use the software in other temperate countries provided that suitable manure analysis and climate data (i.e. rainfall and evapotranspiration) are available.

Decision support tools such as MANNER-NPK are valuable in assisting farmers to assess the fertilizer value of their manures and the potential impact on the environment of different manure application practices. A recent review of decision support tools available in the EU (Cooper et al., 2009) concluded that they must be easy to use and provide fertilizer recommendations that are reasonably accurate, with accuracy improved when they include actual measured values for certain parameters (e.g. manure total N). Furthermore, an effective decision support tool should allow farmers and advisors to investigate 'what if' scenarios, to see the impacts of changes in management on crop yields, profitability and the environment. MANNER-NPK has been designed to meet all these criteria.

\section{Conclusion}

An updated version of the MANNER decision support tool (MANNER-NPK) was developed incorporating improved research information on $\mathrm{N}$ losses and transformations following organic manure application to land. New modules were included to estimate $\mathrm{N}$ losses as nitrous oxide (via denitrification and nitrification) and di-nitrogen (via denitrification) and to estimate autumn crop $\mathrm{N}$ uptake that can decrease the amount of $\mathrm{N}$ at risk from nitrate leaching. Following user and stakeholder feedback, the software functionality was also extended to include predictions of crop $\mathrm{P}, \mathrm{K}, \mathrm{S}$ and $\mathrm{Mg}$ supply, and to present the results as both the fertilizer replacement $(\mathrm{kg} / \mathrm{ha})$ and economic ( $f / \mathrm{ha})$ value of manure applications.

Validation of the ammonia volatilization (cattle slurry, pig slurry, FYM and poultry manure) and nitrate leaching (freely drained and poorly drained soils) modules demonstrated good agreement $(P<0.01)$ between MANNER-NPK predicted and independently measured values. Similarly, MANNER-NPK predictions of crop available $\mathrm{N}$ supply from cattle, pig and poultry manures were in good agreement $(P<0.001)$ with measured values, indicating that MANNER-NPK provides a robust estimate of the fertilizer $\mathrm{N}$ replacement value of different types of farm manures spread under a range of conditions.

\section{Acknowledgements}

Funding for the science underpinning MANNER-NPK was provided by the Department for Environment, Food and Rural Affairs.

\section{References}

Addiscott, T.M. 1977. A simple computer model for leaching in structured soils. Journal of Soil Science, 28, 554-563.

Beckwith, C.P., Cooper, R.J., Smith, K.A. \& Shepherd, M.A. 1998. Nitrate leaching losses following application of organic manures to sandy soils in arable cropping. I. Effects of application time manure type over-winter crop cover and nitrification inhibition. Soil Use and Management, 14, 123-130.

Bradbury, N.J., Whitmore, A.P., Hart, P.B.S. \& Jenkinson, D.S. 1993. Modelling the fate of nitrogen in crop and soil in the years following application of ${ }^{15} \mathrm{~N}$-labelled fertiliser to winter wheat. Journal of Agricultural Science, 121, 363-379.

Burger, M. \& Venterea, R.T. 2008. Nitrogen immobilization and mineralization kinetics of cattle, hog, and Turkey manure applied to soil. Soil Science Society of America Journal, 72, 1570-1579.

Burns, I.G. 1974. A model for predicting the redistribution of salts applied to fallow soils after excess rainfall or evaporation. Journal of Soil Science, 25, 165-178.

Chadwick, D.R., John, F., Pain, B.F., Chambers, B.J. \& Williams, J. 2000a. Plant uptake of nitrogen from the organic nitrogen fraction 
of animal manures: a laboratory experiment. Journal of Agricultural Science, Cambridge 134, 159-168.

Chadwick, D.R., Pain, B.F. \& Brookman, S.K.E. 2000b. Nitrous oxide and methane emissions following the application of animal manures to grassland. Journal of Environmental Quality, 29, 277-287.

Chambers, B.J., Smith, K.A. \& Cross, R.B. 1994. Effect of poultry manure application timing on nitrogen utilisation by cereals. In: Animal waste management (ed. J.E. Hall), Proceedings of the Seventh Technical Consultation of the ESCORENA Network on Animal Waste Utilisation, REUR Technical Series 34, pp. 199-205. FAO, Rome.

Chambers, B.J., Williams, J. \& Smith, K.A. 1996. Residual effects of poultry manure and fertiliser nitrogen applications. In: Progress in nitrogen cycling studies (eds O. Van Cleemput, G. Hofman \& A. Vermoesen), pp. 183-190. Kluwer Academic Publishers, Dordrecht.

Chambers, B.J., Lord, E.A., Nicholson, F.A. \& Smith, K.A. 1999. Predicting nitrogen availability and losses following application of organic manures to arable land: MANNER. Soil Use and Management, 15, 137-143.

Chambers, B.J., Smith, K.A. \& Pain, B.F. 2000. Strategies to encourage better use of nitrogen in animal manures. Soil Use and Management, 16, 157-161.

Clemens, J. \& Ahlgrimm, H.J. 2001. Greenhouse gases from animal husbandry: mitigation options. Nutrient Cycling in Agroecosystems, 60, 287-300.

Clough, T.J., Jarvis, S.C. \& Hatch, D.J. 1998. Relationships between soil thermal units, nitrogen mineralisation and dry matter production in pastures. Soil Use and Management, 14, 65-69.

Cooper, J., Carmichael, A., Stockdale, E., Quemada, M., ThorupKristensen, K., van der Burgt, G.-J. \& Scholberg, J. 2009. Inventory of existing decision support tools for farm level $\mathrm{N}$ management in the EU. Toolbox of cost-effective Strategies for On-farm Reductions in $N$ Losses to Water: WP 1 Deliverable 1.4. Available at: http://research.ncl.ac.uk/nefg/ntoolbox/pdf/ NTOOLBOX_D1-4.pdf accessed 10/04/2013

Davison, P.S., Withers, P.J.A., Lord, E.I., Betson, M.J. \& Stromqvist, J. 2008. PSYCHIC - A process-based model of phosphorus and sediment mobilisation and delivery within agricultural catchments. Part 1: model description and parameterisation. Journal of Hydrology, 350, 290-302.

Defra (Department for Environment Food and Rural Affairs). 2010. The fertiliser manual (RB209). The Stationery Office, Norwich. ISBN 978-0-11-243286-9

Douglas, C.L. Jr \& Rickman, R.W. 1992. Estimating crop residue decomposition from air temperature, initial nitrogen content and residue placement. Soil Science Society of America Journal, 56, 272-278.

Gooday, R.D., Anthony, S.G. \& Fawcett, L.E. 2008. A field scale model of soil drainage and nitrate leaching for application in Nitrate Vulnerable Zones. Environmental Modelling \& Software, 23, 1045-1055.

Granli, T. \& Bøckman, O. 1994. Nitrous oxide from agriculture. Norwegian Journal of Agricultural Sciences, Supplement 12, 1-128.

IPCC. 1997. Guidelines for national greenhouse gas inventories, volume 3, greenhouse gas inventory reference manual. IPCC WGI Technical Support Unit, Hadley Centre, Meteorological Office, Bracknell, UK.
IPCC. 2006. IPCC guidelines for national greenhouse gas inventories. Prepared by National Greenhouse Gas Inventories Programme (eds H.S. Eggleston, L. Buendia, K. Miwa, T. Ngara \& K. Tanabe). IGES, Hayama, Japan.

IPCC. 2007. Climate change 2007. In: the physical science basis. Contribution of working group I to the fourth assessment report of the intergovernmental panel on climate change, pp. 210-214. Cambridge University Press, Cambridge.

Jackson, D.R. \& Smith, K.A. 1997. Animal manure slurries as a source of nitrogen for cereals: effect of application time on efficiency. Soil Use and Management, 13, 75-81.

Klausner, S.D., Kanneganti, V.R. \& Bouldin, D.R. 1994. An approach for estimating a decay series for organic nitrogen in animal manures. Agronomy Journal, 86, 897-903.

Misselbrook, T.H., Chadwick, D.R., Pain, B.F. \& Headon, D.M. 1998. Dietary manipulation as a means of decreasing $\mathrm{N}$ losses and methane emissions and improving herbage $\mathrm{N}$ uptake following application of pig slurry to grassland. Journal of Agricultural Science, 130, 183-191.

Misselbrook, T.H., Smith, K.A., Johnson, R.A. \& Pain, B.F. 2002. Slurry application techniques to reduce ammonia emissions: results of some UK field-scale experiments. Biosystems Engineering, 81, 313-321.

Misselbrook, T.H., Nicholson, F.A. \& Chambers, B.J. 2004. Predicting ammonia loss following the application of livestock manure to land. Bioresource Technology, 96, 159-168.

Misselbrook, T.H., Nicholson, F.A., Chambers, B.J. \& Johnson, R.A. 2005. Measuring ammonia emissions from land applied manure: an intercomparison of commonly used samplers and techniques. Environmental Pollution, 135, 389-397.

Ryden, J.C., Skinner, J.H. \& Nixon, J. 1987. Soil core incubation system for the field measurement of denitrification using acetylene inhibition. Soil Biology and Biochemistry, 28, 1541-1544.

Schröder, J.J., Uenk, D. \& Hilhorst, G.J. 2007. Long-term nitrogen fertilizer replacement value of cattle manures applied to cut grassland. Plant and Soil, 299, 83-99.

Smith, K.A., Jackson, D.R., Misselbrook, T.H., Pain, B.F. \& Johnson, R.A. 2000. Reduction of ammonia emission by slurry application techniques. Journal of Agricultural Engineering Research, 77, 277-287.

Sogaard, H.T., Sommer, S.G., Hutchings, N.J., Huijsmans, J.F.M., Bussink, D.W. \& Nicholson, F. 2002. Ammonia volatilization from field-applied animal slurry - the ALFAM model. Atmospheric Environment, 36, 3309-3319.

Sommer, S.G. \& Ersboll, A.K. 1994. Soil tillage effects on ammonia volatilisation from surface-applied cattle slurry. Journal of Environmental Quality, 23, 493-498.

Swift, R., Heal, O.W. \& Anderson, J.M. 1979. Decomposition in terrestrial ecosystems. Blackwell Scientific Publications, Oxford.

Thorman, R.E., Harrison, R., Cooke, S.D., Ellis, S., Chadwick, D.R., Burston, M. \& Balsdon, S.L. 2003. Nitrous oxide emissions from slurry- and straw-based systems for cattle and pigs - in relation to emissions of ammonia. In: Proceedings of the $S A C /$ SEPA Conference: Agriculture, Waste and the Environment (eds I. McTaggart \& L. Gairns), pp. 26-32. The Scottish Agricultural College, Edinburgh, Scotland.

Thorman, R.E., Webb, J. \& Yamulki, S. 2006. Rapid incorporation of solid manure as a best management practice? In: Proceedings of 
the SAC/SEPA Conference Agriculture and the Environment IV: Managing Rural Diffuse Pollution (eds L. Gairns, K. Crighton \& B. Jeffrey), pp. 249-252. The Scottish Agricultural College, Edinburgh, Scotland.

Thorman, R.E., Chadwick, D.R., Harrison, R., Boyles, L.O. \& Matthews, R. 2007. The effect on $\mathrm{N}_{2} \mathrm{O}$ emissions of storage conditions and rapid incorporation of pig and cattle FYM into arable land. Biosystems Engineering, 97, 501-511.

Williams, J.R., Chambers, B.J., Bhogal, A., Chadwick, D.R. \& Pain, B.F. 1999. Organic nitrogen release from farm manures. In: Eleventh nitrogen workshop - book of abstracts, pp. 381-381. INRA, Reims, France. [abstract]
Williams, J.R., Chambers, B.J., Chadwick, D.R., Bhogal, A. \& Pain, B.F. 1998. Field studies of farm manure organic nitrogen mineralisation. In: Proceedings of the Eighth International Conference of the FAO/ESCORENA Network on Recycling of Agricultural Municipal and Industrial Residues in Agriculture RAMIRAN, pp. 101-111. Cemagref Editions, France.

Williams, J.R., Sagoo, E., Chambers, B.J., Cross, R.B. \& Hodgkinson, R.A. 2006. Nitrogen losses following cattle slurry applications to a drained clay soil. In: Proceedings of the SAC/SEPA Conference Agriculture and the Environment IV: Managing Rural Diffuse Pollution (eds L. Gairns, K. Crighton \& B. Jeffrey), pp. 267-271. The Scottish Agricultural College, Edinburgh, Scotland. 